\title{
Local Building Regulators' Institutionalised Behaviour Towards Mass Customised Housing (MCH)
}

\author{
Hasniyati Hamzah* and Suzila Mislam \\ Centre for Sustainable Urban Planning \& Real Estate, Faculty of Built Environment, University of \\ Malaya, Malaysia \\ *Corresponding author: hasniyati@um.edu.my
}

\begin{abstract}
Mass Customised Housing ( $\mathrm{MCH})$ is an innovation in house production that could potentially transform developers' business models due to its buyer-friendly template by offering customised houses that can fulfil part or most of buyer's housing requirements at reasonable prices, thus securing customer loyalty and market share in the long run. Thus far, the body of literature on MCH only focuses either on the technical or the financial side of $\mathrm{MCH}$ implementation, with a discernible lacuna in the regulatory response. A broad institutional approach frames this study whereby a questionnaire survey with close and open ended questions was conducted on local building regulators to examine their attitude towards $\mathrm{MCH}$ and to explore potential issues pertaining to $\mathrm{MCH}$ implementation. A total of 133 questionnaires were sent to building regulators in Peninsular Malaysia, with a response rate of 28.6\%. Quantitative data was analysed to yield descriptive statistics whilst qualitative data was analysed based on thematic analysis. Quantitative results showed a strong positive acceptance of MCH within the current regulatory environment, yet qualitative findings revealed respondents' concerns about stakeholders' disconnect, MCH's compatibility with the current system and development actors' actual motivations. Findings give an insight into the attitude of local building regulators in balancing their statutory roles with furthering developers' economic objectives and house buyers' social objectives.
\end{abstract}

Keywords: Mass Customised Housing ( $\mathrm{MCH})$, local building regulators, housing innovation, institutionalised behaviour

Acknowledgement: This paper presents research findings under University of Malaya Research Grant (UMRG) Ref No. RP007E-13SUS

\subsection{INTRODUCTION}

Mass Customised Housing (MCH) can be perceived as a business model that promotes both sustainable living among house buyers and economic competitiveness among house producers or developers. In essence, MCH offers customisation to new houses based on house buyers' preferences at costs comparable to mass production. The customisation spectrum in $\mathrm{MCH}$ ranges from low (customised standardisation) to high (pure customisation) (Barlow \& Ozaki, 2003). In many countries - for instance Japan, Korea, Netherlands - MCH is already a successful strategy among house producers. In some countries - for instance Thailand, Australia and China - MCH is considered at its infancy stage but steadily growing in prominence. With many economies having acknowledged the many benefits carried by $\mathrm{MCH}$, the question for countries that have yet to offer $\mathrm{MCH}$ is no longer if $\mathrm{MCH}$ is going to be introduced, but when and to what extent will $\mathrm{MCH}$ be implemented. 
$\mathrm{MCH}$ can be considered a recent concept in house building as evidenced by the promulgation of MCH research (see among others Andújar-Montoya et al., 2015; Duarte, 2005; Gao, 2014; Noguchi, 2003; Noguchi \& Hadjri, 2009; Schoenwitz et al., 2012; Shin et al., 2008). With costs being the main concern for developers, it is important for $\mathrm{MCH}$ to be technically and economically viable. Among the vast amount of literature, studies on the implementation of MCH are discerned to have focused either on the technical side - for instance, determining the shape grammar (for instance Duarte, 2005), exploring computing in design (for instance Gao, 2014; Shin et al., 2008) and devising a construction management system towards MCH (for instance Andújar-Montoya et al., 2015), or the financial side, for instance, determining the specification options to be offered (for instance Schoenwitz et al., 2012).

However, the production of housing is subject to regulatory control in many of its aspects. The government oversees the quantity and quality of housing through planning, building and environmental controls; these controls have implications to $\mathrm{MCH}$ current and future implementations (Gao, 2014). A review of the MCH literature reveals a gap in understanding how MCH interacts with the regulatory framework. Approaches in studies into the effect of regulations on housing provision may be categorised into the mainstream econometric modelling and the lesser utilised institutional analysis (Hamzah, 2013). Although both approaches are valid, investigations into institutionalised behaviour is argued as a better approach as it enables a deeper insight into how regulation is interpreted and mediated by housing actors. The main caveat in the use of institutional approaches is obvious; there is a lack of generalisability due to their context- and temporal-specific nature (Ball, 1998, 2003).

In the case of Malaysia, MCH has yet been systematically implemented other than the options for some limited superficial building features. The receptiveness of regulators towards MCH is particularly interesting to know within a market that was once described as being heavily regulated (Bertaud \& Malpezzi, 2001; Hannah et al., 1989; Malpezzi \& Mayo, 1997). Since regulators are interpreters of legislation and mediators between legislation and development activity, the perception and behaviour of regulators will serve as benchmark of the regulatory environment that would eventually control MCH.

This paper examines the attitude of local building regulators towards $\mathrm{MCH}$ implementation within a broad institutional framework. Both quantitative and qualitative data was obtained via a questionnaire survey to determine the general outlook of regulators pertaining to $\mathrm{MCH}$ and potential issues with $\mathrm{MCH}$ implementation. This paper is structured thusly. First, the literature review will provide the conceptual framework of this paper by situating the query within the $\mathrm{MCH}$ and institutionalism literatures. Next, the methodology section outlines the parameters covered by the questionnaire survey. In the subsequent results and discussion section, attitude of building regulator respondents will be reviewed by presenting, firstly, results of quantitative data analysis and subsequently, qualitative data findings and reconciling the results of both analyses. Finally, implications for $\mathrm{MCH}$ implementation within the regulatory context of Malaysia will be presented in the conclusion and recommendations section.

\subsection{LITERATURE REVIEW}

\subsection{A Primer on Mass Customised Housing (MCH)}

Mass customisation (MC) is commonly defined as the delivery of products offering variety that is based on individuality and thus help fulfil customers' requirements, at scale economies that enables prices comparable to standard products (Barlow, 1999; Barlow et al., 2003; Barlow \& Ozaki, 2003; Naim \& Barlow, 2003; Noguchi, 2003; Pine II, 1999; Zipkin, 2001). Noguchi (2003) even suggested that even at a higher price, Mass Customised Housing (MCH) still garnered support from house buyers due to high quality offered. Subsequent explanation of the 'experience economy' 
paradigm provided an alternative explanation about the appeal of $\mathrm{MCH}$ : apparently consumers' involvement in the production process may constitute emotional investment that can add value to the product (Pine \& Gilmore, 2011; Sundbo \& Sørensen, 2013). In construction, the customisation element may reduce construction waste and enhance customer satisfaction (Barlow, 1999; Tseng \& $\mathrm{Du}, 1998$ ). Thus, $\mathrm{MCH}$ can be a good business strategy for developers in the long run if developers succeed in offering the right 'specification options' such as spatial configurations and options for lighting, finishes, appliances and energy producing components (Schoenwitz et al., 2012).

This innovation in housing production encompasses the post-modern idea of the home as a combination of physical, financial, social and psychological aspects of dwelling (Schoenwitz et al., 2012). Houses that are built according to some, if not all, of the individual customer's preferences has driven the efforts to transform the house building industry (Barlow \& Ozaki, 2003). For instance, the UK government called for housing innovation initiatives in terms of improving housing designs, building technologies and supply chain management (Barlow et al., 2003). As a production strategy, $\mathrm{MCH}$ is enabled though the modularisation of product design, flexibility in process and supply chain integration (Fogliatto et al., 2012). Modularisation entails engineering the product customisation process into a routine that uses standardised parts that is able to be assembled in different configurations (Barlow et al., 2003). Although stocks should be kept at a minimum level, the service level is to be kept at the maximum level. This allows developers to balance the efficient production processes with higher level of choices (Barlow et al., 2003; Naim \& Barlow, 2003).

Mass customisation occupies a number of customisation spectrum i.e. Customised standardisation, Tailored customisation and Pure customisation (Barlow et al., 2003). In a mature mass customisation-led market, architects and industrial designers would use an integrated system based on industry-wide standards for both building components and digital technologies. In Japan, for instance, house manufacturers offer an almost pure MCH model. To illustrate, Sekisui Heim Ltd has been manufacturing customised housing at a mass scale since after the Second World War (Puligadda et al., 2010). At the other end of the MCH spectrum is limited customisation; an example is Optional Component Scheme (OCS) by the Housing Development Authority of Singapore that offers some specification options for its new flats (Singapore HDB, 2015). To apply Ball's Structure of Provision principle, the different MC model between countries can be explained by pre-existing institutional factors, such as construction technology, legal framework, local building material and labour skills that shape the local house building industry (Ball, 2003). As such, MCH must not be construed as only resulting in an unlimited permutation of the final product.

\subsection{An Overview of Institutionalism in Property Studies}

The study of institutions has attracted prominent researchers - Veblen, North, Samuels and Hodgson among others - in unpacking the effects of institutions on economic activities. A review of institutional economics literature revealed that the unit of analysis has changed over time; from the study of the individual (old institutional economics) to the social and legal norms (new institutional economics or NIE) and more recently back to the individual. According to Hodgson, the study of institutions involves the examination of "human activity partly through the continuing production and reproduction of habits of thought and action" (1998, p. 180). Importantly, Hodgson (2000) supported the tradition of old institutional economics in the focus on the individual whereby "the individual is molded by social and institutional circumstances" (p. 327). The examination of 'human habits' in institutional approaches is underpinned by the belief that the market in itself does not represent the economy, but rather the economy should be seen as fundamentally processual (Samuels, 1995).

Institutionalism is a valuable research approach in property studies especially when studying development processes (Adams, 2008; Adams et al., 2012; Awuah \& Hammond, 2014; Hamzah \& Wan Abd. Aziz, 2013; Yates \& Worzala, 2013). Based on institutionalist perception, the housing industry is characterised by pre-existing institutions - such as legal framework, building technology, labour skills, political situation and economic conditions - and a multiplicity of actors - including 
developers or house builders, professionals, planners and various government departments - the interactions of which will bear upon the housing outcomes (Ball, 2003). The pre-existing institutions can be described as the 'playing field' that both control whilst simultaneously being moulded by agents' interactions (Ball, 1998). On the other hand, the actors within the structure of housing provision have roles to play, displaying distinct economic behaviours among their groups and in interactions with other groups (Ball, 1998). The institutional dynamic caused by interactions of actors and institutional frameworks can have a considerable impact on housing outcomes. To illustrate, institutional approaches have revealed the effect of a country's housebuilding industry on the quantity and quality of housing in the country (Ball, 2003), how new regulations were tempered by actors despite perceptions of overregulation (Hamzah \& Wan Abd. Aziz, 2013), why some housing markets remained largely unaffected by the Subprime Crisis of 2008 (Murphy, 2011) and understanding how some landlords display counter-intuitive non-pecuniary motives in their renting and development decisions (Satsangi, 2005). These selected examples reflect how the complexities of the market may be unpacked and examined against well-developed sets of principles and supported by a vast amount of available literature.

Within the context of this study, present within the housing provision structure is institutionalised behaviour that may ultimately affect $\mathrm{MCH}$ implementation. Ball (1986) provides a practical platform to study phenomena in housing provision by proposing that the structure of housing provision, which comprises the dimensions of production, consumption and exchange, may be studied holistically or according to each dimension. The production dimension is the focus of MCH whereby a selection of options will be chosen by the user and conveyed to the producer to be incorporated in the final product (Schoenwitz et al., 2012). Thus, a key feature of MCH is process flexibility to allow for customisation of housing features (Barlow, 1999; Barlow et al., 2003; Barlow \& Ozaki, 2003).

\subsection{MCH and Institutions}

Figure 1 shows how advances in information technology have facilitated the conveyance of information between user and designer (architect). The model by Gao (2014) indicates that the platforms in which user requirements are translated into design parameters involve database and parametric design principles, whereas the construction of customised units is driven by Building Information Management (BIM) and manufactured building products. According to Gao, the web interface that enables user-designer interaction also could be used by other development actors, including the government in implementing and enforcing development control. Thus, the computeraided process flexibility may be impeded by the local authority's interpretation of planning and design guidelines (Barlow \& Ozaki, 2003), which is in turn influenced by extraneous factors such as public interest and political input (Campbell \& Marshall, 2000), overlapping policy instruments (Malpezzi \& Mayo, 1997) and the local economy (Bramley \& Leishman, 2005) and in the case of Malaysia, insufficient manpower, in terms of both inadequate number and skills of personnel (Sufian \& Ab. Rahman, 2008). The resultant inefficiencies observed in Malaysia include ad-hoc site inspection by the authorities on housing development sites (Sufian \& Ab. Rahman, 2008), delays in processing development approval applications (Agus, 2002; Sufian \& Ab. Rahman, 2008), innovation suffocation (Agus, 2002) and misinformed planning decisions (Rameli et al., 2006). 
Figure 1: Actors and networks within MCH production

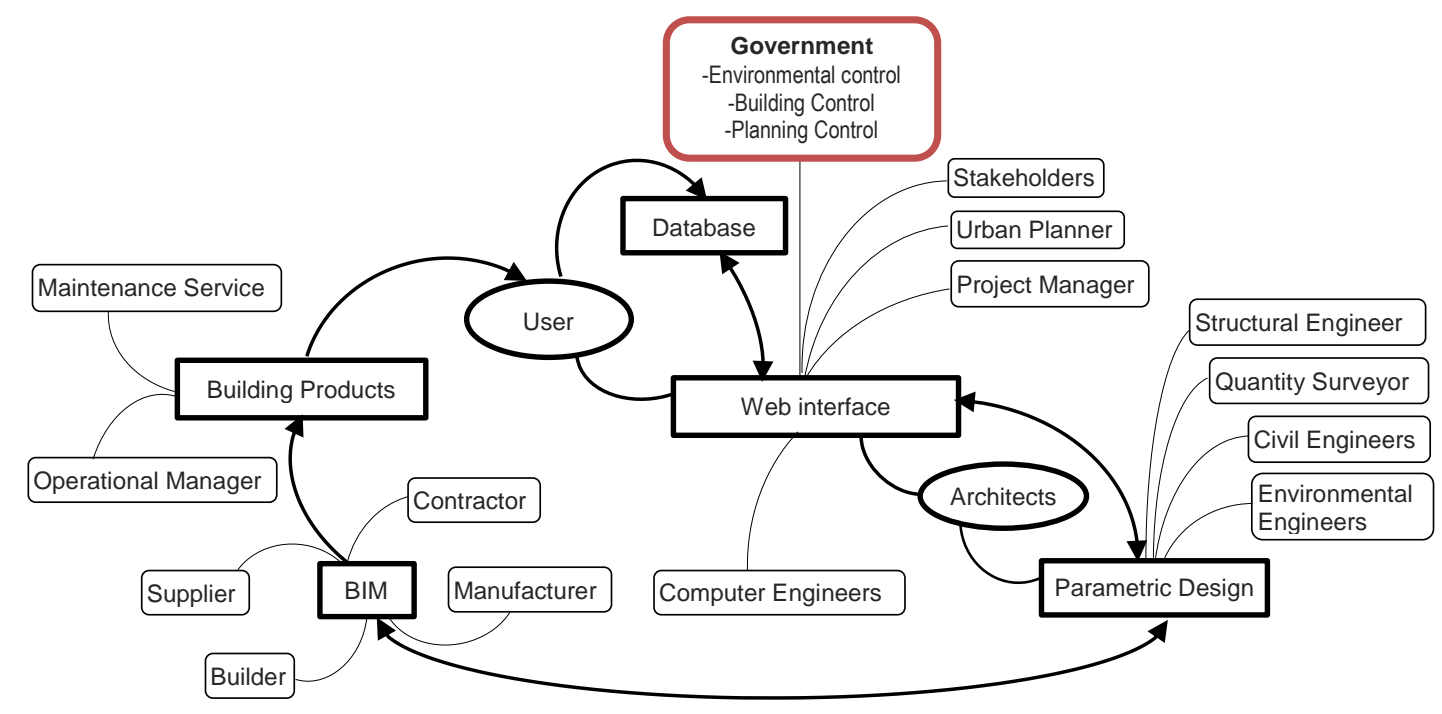

Source: $(G a o, 2014)$

\subsection{Conceptual Framework of this Paper}

The seminal works by Adams et al. (2005) and (Ball, 1986) guide the formulation of the conceptual framework of this paper (Figure 2).

Adams et al. elucidated that the types of institutionalised rules that shape the land and property market can be divided into formal, informal and network of relationships. To further clarify, 'formal rules' can encompass legislation, guideline or legal requirements, 'informal rules' can include behaviours of actors and 'network of relationships' refer to the relations between actors or between actor and rules. An inquiry into the compatibility of $\mathrm{MCH}$ in a specific housing market must firstly determine its fit within the pre-existing regulatory framework. Regulations that oversee housing innovations have been described as either being traditional and prescriptive in nature or part of a performance-based portfolio of policies (Gann et al., 1998). Gann et al. argued that the second group of regulations are more potent in driving innovation in terms of incentivising the market and providing the necessary institutional frameworks. Next, the inquiry should move to the regulatory environment within which $\mathrm{MCH}$ would be implemented. This entails examining the behaviours of the actors involved in the regulation of MCH. Examinations of actors' perception are useful to yield an insight into the effectiveness of regulations (Yau, 2009). Finally, the interactions among actors and between actors and the regulatory framework should inform on the actual effects of regulations on MCH.

Ball originally mooted the Structure of Provision (SOP) thesis as “...the product of particular, historically determined social relations associated with the physical processes of land development, building production, the transfer of the completed dwelling to its final user and its subsequent use" (1983, p. 17). Subsequently, the SOP thesis was refined and described as the study of social relations of actors and the effects of this dynamic on housing within the dimensions of production, consumption and exchange of housing (Ball, 1986; Ball \& Harloe, 1992). The SOP provides a highly practical framework to examine various housing phenomena as evidenced by a multitude of works (see for instance Burke \& Hulse, 2010; Hamzah, 2012; Hamzah \& Wan Abd. Aziz, 2013; Murphy, 2011; Satsangi, 2005, 2011; Satsangi \& Dunmore, 2003). As recommended by Ball, a researcher may decide to focus on examining one, a combination, or all of three SOP dimensions i.e. production, 
consumption and exchange. In accordance to the aim of this paper, only the production aspect of housing (i.e. housing approval by the local regulators) is considered.

With reference to Figure 2, this paper conducts an empirical investigation on the second layer of regulation (informal rules), whereas the first layer (formal rules) and third layer (network of relationships) of the regulatory environment will be critically discussed as the context in the immediate following section. Therefore, this paper actually covers all three types of institutionalised rules over MCH implementation.

Figure 2: Conceptual framework of this paper



Source: Adapted from Adams, Watkins, et al. (2005) and Ball (1986)

\subsection{THE REGULATORY CONTEXT}

A major concern about the introduction of any new concept in housing development is whether the concept complies with the existing regulations. This section provides an overview of the regulatory framework that oversees housing development in Malaysia and the agencies involved in the implementation of those regulations. As adapted from Adams et al., this discussion concerns the formal rules over $\mathrm{MCH}$ implementation and the corresponding network of relationships. Here, the important housing statutes will be outlined alongside the major stakeholders concerned.

In the past, Malaysia has been described by the World Bank as being one of the most heavily regulated housing market (Bertaud \& Malpezzi, 2001; Hannah et al., 1989; Malpezzi \& Mayo, 1997). Since then, a number of improvements have been carried out to streamline the regulatory framework over housing development (Hamzah \& Wan Abd. Aziz, 2013). Nonetheless, the basic regulatory structure remains the same as reflected by Figure 3. Housing development is controlled at three levels i.e. federal, state and local levels by the use of a number of different regulatory instruments. As seen in Figure 3, the regulatory instruments differ in terms of authority and quantity, with the Constitution of Malaysia having the utmost authority over the remainder of the primary and secondary legislation. Malaysia practices a three-tier government system involving the Federal Government at country level, the State Government at the state level and the Local Authority at the local level. The separation of statutory power is accorded by Article 74 of the Malaysian Constitution; the Federal Government is empowered to legislate over items under the Federal List and similarly the State Government may make laws for items enumerated in the State List. ${ }^{1}$ Both the Federal and State Governments jointly legislate over items in the Concurrent List. Housing is a Concurrent List item ${ }^{2}$ alongside an important element of development control i.e. town planning, ${ }^{3}$ yet paradoxically land is vested under the State

\footnotetext{
${ }^{1}$ The Ninth Schedule contains List I (Federal List), List II (State List) and List III (Concurrent List).

${ }^{2}$ Item 9C, List III, the Ninth Schedule.

${ }^{3}$ Item 5 of List III, the Ninth Schedule.
} 
Government. ${ }^{4}$ Effectively, the result of this division of power affords the State Government vast constitutional right over the regulation of housing.

Figure 3: Hierarchies of the Malaysian government system and the formal written law

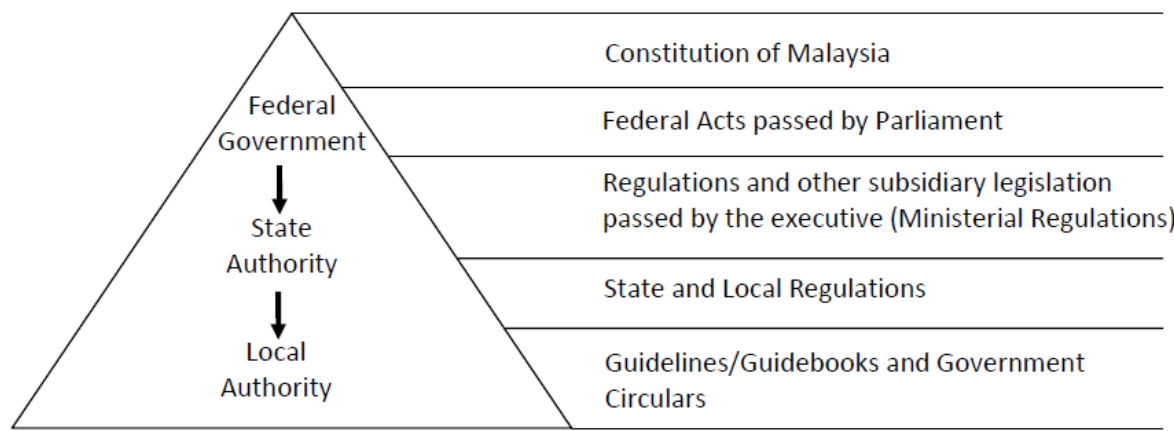

Source: Hamzah (2012)

Besides the Malaysian Constitution, developers and regulators also have to comply with the requirements of housing-related legislation such as the Housing Development Act (Control and Licensing) Act 1966, National Land Code 1965, Street, Drainage and Building Act 1974 and Uniform Building By-Laws 1984, Local Government Act 1976, Town and Country Planning Act 1976, Environmental Quality Act 1974, Strata Titles Act 1985 and Strata Management Act 2013. As MCH involves new dwelling units, the focus is on pre-construction regulations, in particular building control as MCH mostly concerns the design and interior features of the building. Since 2007, the approval for most new developments is processed at the One Stop Centre at the Local Authority. In the case of $\mathrm{MCH}$, the most relevant segment of building control is building plan approval. The main procedures pertaining to building plan approval are set out in Street, Drainage and Building Act 1974 and Uniform Building By-Laws 1984, whereas the approving authority would be the building control department or normally known as the Building Unit of the Local Authority.

In Malaysia, $\mathrm{MCH}$ can be categorised together with housing innovations that involve the installation or adaption of cosmetic building features, for instance lifestyle housing, and those involving unit-partitioning, for instance the "dual-key" concept. As with these innovations, there are no foreseen conflicts between $\mathrm{MCH}$ and existing legislation. Nevertheless, the regulatory environment also depends on the implementation of the legal provisions. Thus, the interpretation and mediation of regulators also play an important role in determining the severity of the regulatory environment (Hamzah \& Wan Abd. Aziz, 2013). Ultimately, it is not sufficient to only examine the pertinent regulations (formal rules) and the network of actor/actor and actor/rules relations (network of relationships), but also the institutionalised behaviour of the actors (informal rules).

\subsection{METHODOLOGY}

This study therefore aims to explore the institutionalised behaviour of local building regulators in relation to housing innovation, and with particular focus on $\mathrm{MCH}$. It used a postal questionnaire survey to ascertain their receptiveness of $\mathrm{MCH}$ as an innovation in housing, and also the potential barriers to $\mathrm{MCH}$ in relation to their attitudes, that have been shaped by their background, perceptions and experiences. The questionnaire was divided into three parts namely respondent's details, attitude on housing innovation in general and attitude on $\mathrm{MCH}$. Responses were captured in both close and open ended questions. The open-ended question was to probe on the accommodativeness of the

\footnotetext{
${ }^{4}$ Item 2 of List II, the Ninth Schedule.
} 
regulatory environment towards new ideas in housing development, with the aim at exploring respondents' views on $\mathrm{MCH}$ as a novel housing concept.

Purposive sampling is used to select the sample in this study. Due to the specific nature of building control, the population of the survey was carefully determined. Firstly, the local authorities must be within economic regions that were experiencing growth and were most likely to be experiencing housing demand. Based on that criterion, 32 local authorities were determined to be of suitable size and credence. Then, the number of officers at the building control department of those local authorities was obtained by either extracting from the official website or by personally calling the Building Unit. This exercise yielded a target population of $133(n=133)$. A total of 133 questionnaires were sent by post to these officers; 38 completed surveys were returned giving a response rate of 28.6\%. Quantitative data from the completed questionnaire was analysed using the Statistical Package for the Social Science (SPSS) software to yield descriptive statistics i.e. frequency and mean score, whilst the qualitative data was coded and analysed manually using thematic analysis.

Table 1 tabulates the composition of the respondents. All respondents indicated receiving tertiary-level education, with most of them at undergraduate level $(94.7 \%)$ and a small proportion $(5.3 \%, f=2)$ at postgraduate level. A vast majority of respondents had Built Environment background as their undergraduate field of study $(78.9 \%, f=30)$ compared to Non-built Environment background $(21.1 \%, \mathrm{n}=8)$. In terms of work experience at the local authority, results indicated that almost twothirds of respondents had at least five years' working experience $(65.8 \%, f=25)$. The majority of respondents $(52.6 \%, f=20)$ indicated being junior officers, whilst those at executive level represented $31.6 \%(f=12)$ of respondents and those at managerial level represented $15.8 \%(f=6)$ respondents. From 38 respondents, almost a third $(31.6 \%, f=12)$ indicated being members of professional bodies because there is less motivation for public officers to obtain professional membership compared to professionals in private practice. Overall, results of respondents' profile indicated that they had good authority to opine about MCH implementation as they possessed the appropriate tertiary background, work experience, position in organisation and professionalism.

Table 1: Profile of respondents

\begin{tabular}{cccc}
\hline Variable & Profile details & $\boldsymbol{F}$ & $\%$ \\
\hline Education level & Undergrad (Dip \& Degree) & 36 & 94.7 \\
& Postgrad (Masters \& above) & 2 & 5.3 \\
Undergraduate field of study & Built Environment field & 30 & 78.9 \\
& Non-Built Environment field & 8 & 21.1 \\
Work experience in local authority & $<5$ years & 13 & 34.2 \\
& $5-10$ years & 10 & 26.3 \\
Current position in organisation & $>10$ years & 15 & 39.5 \\
& Junior Officer & 20 & 52.6 \\
Membership in professional body & Executive Level & 12 & 31.6 \\
& Managerial Level & 6 & 15.8 \\
& Yes & 12 & 31.6 \\
& No & 26 & 68.4 \\
\hline
\end{tabular}

\subsection{RESULTS AND DISCUSSION}

This section presents the findings of the survey. It also includes a discussion on these findings, particularly pertaining to their impact on $\mathrm{MCH}$ implementation. The Cronbach's alpha internal consistency reliability test was run on 13 Likert scale items on respondents' attitude, giving a coefficient of 0.711 , showing average reliability value according to Chua (2013).

\subsection{Quantitative Results}

Regarding their role in facilitating housing innovation, the majority of respondents considered that they have important or very important facilitative role $(89.5 \%, f=34)$ whilst only $4(10.5 \%)$ 
respondents were unsure of their facilitative role. When asked about their attitude towards housing innovation, almost all respondents indicated being receptive $(97.4 \%, f=37)$. Their individual receptiveness was mirrored by their perception on their department accommodativeness $(92.1 \%, f=35)$. Overall, these indications signalled a general acceptance and strong support of an innovative housing development concept among respondents. Importantly, this has positive implications on the general regulatory environment in housing development as argued earlier by Hamzah and Wan Abd. Aziz (2013)

However, the general optimistic response above was somewhat tempered by results on the inefficiencies within the incumbent regulatory implementation. To further probe on the potential regulatory barriers to $\mathrm{MCH}$, the respondents were asked to pinpoint what they perceived to be the main hindrance specifically with regard to their department and generally from the viewpoint of the current development control environment. A number of possible barriers identified from literature were presented as choice. Table 2 presents the regulatory barriers to $\mathrm{MCH}$ as perceived by respondents.

Table 2: Barriers to housing innovation

\begin{tabular}{lcc}
\hline & \multicolumn{2}{c}{ Frequencies } \\
Barrier & Department & General \\
\hline Rigid building standards \& requirements & $11(28.9)$ & $12(31.6)$ \\
Outdated knowledge among Local Authority's technical staff about latest & $4(10.5)$ & $9(23.7)$ \\
developments in housing industry & & \\
Strict time frame when evaluating building plans submitted by developers & $6(15.8)$ & $2(5.3)$ \\
Local Authority's technical staff lack of interest in developers business strategies & $2(5.3)$ & $4(10.5)$ \\
The opposite motivations of Local Authority's technical staff (public interest) \& & $5(13.2$ & $0(0)$ \\
developers (profit) prevent meaningful cooperation & $4(10.5)$ & $2(5.3)$ \\
Lack of skilled technical assistants to evaluate new building concepts \& designs & $5(13.2)$ & $9(23.7)$ \\
Others & $37(97.4)$ & $38(100.0)$ \\
Total & $1(2.6)$ & - \\
Missing System & $38(100.0)$ & $38(100.0)$ \\
\hline Total & &
\end{tabular}

Note: Figures given in parentheses are percentage

From the above results, the majority of respondents expressed that the main barrier to housing innovation was the rigid building standards and requirements, with $28.9 \%$ respondents perceiving stringent codes at department level and $31.6 \%$ respondents perceiving that the general development control exhibited inflexible regulation. This result seemed to reflect the World Bank's 1989 research into the regulation of housing in Malaysia that cited a restrictive regulatory environment (see Hannah et al., 1989). Despite efforts by the government to streamline the multifarious provisos and procedures, e.g. by establishing the One-Stop-Centre, respondents in this study still maintained perceptions of an opaque and rigid regulatory environment being adopted at the department level and also within the development control structure generally. This perception can be interpreted as reality by the respondents and ultimately may influence the decision-making process among respondents.

Whilst there was a majority agreement on the rigidity of building standards at department and general levels, such agreement was not replicated in the remainder of the barriers. For innovation barriers at the department level, the second most selected item was the strict time frame when evaluating building plans submitted by developers (15.8\%). Following the 2007 streamlining exercise, the building control department at local authorities has to process new building plan applications within 37 days. In some cases, the application has to be processed within 31 days. This time limitation favours conventional developments, whereas developments with new concepts would require more time to scrutinise and could stretch the time limit. The remainder of the departmental barriers is arranged as follows in the descending order according to respondents' selection: opposite motivations of local authority technical staff (public interest) \& developers (profit) prevent meaningful cooperation (13.2\%), outdated knowledge among technical staff about latest developments in housing industry $(10.5 \%)$, which tied with the lack of skilled technical assistants to evaluate new building concepts and 
designs, and finally, lack of interest among local authorities' technical staff in developers' business strategies $(5.3 \%)$.

In comparison, the second most selected barrier based on the current development control environment was the outdated knowledge among technical staff about latest developments in housing industry (23.7\%). The concern about the deficit of knowledge among technical support staff i.e. draftsmen and assistant officers had been noted in much earlier literature (see Agus, 2002). Unlike the project team with a housing developer, LA technical staff has no commercial interest in keeping abreast with the latest trends in housing concepts, design, construction and materials. In addition, dissimilar to developer's project team that deals with only a few projects at the same time, the LA technical staffs have to vet through voluminous applications within a prescribed time period. Once confirmed into their posts at the local authority, these technical staffs have no motivation or time to update these areas of knowledge. The remainder of barrier within the current development control environment is thusly chosen by respondents: Lack of interest among Local Authorities' technical staff in developers' business strategies $(10.5 \%)$, strict time frame when evaluating building plans submitted by developers $(5.3 \%)$ and lack of skilled technical assistants to evaluate new building concepts and designs $(5.3 \%)$.

Respondents were given five statements on the characteristics of $\mathrm{MCH}$ whereby they indicated their degree of agreement on a 5-point Likert scale with $1=$ "Strongly disagree" and 5="Strongly agree". The aim of this section of the questionnaire was to ascertain respondents' attitude towards $\mathrm{MCH}$ characteristics. The mean scores were calculated to rank the characteristics' agreeableness among respondents. Results showed that the most appealing characteristic of $\mathrm{MCH}$ is the long-term benefit to development control as a house that already satisfies the needs of its occupants would most unlikely undergo illegal renovations $(\mu=3.92)$. This feature is highly favourable to respondents as it has a direct bearing on their scope of work at building control. The second-most appealing characteristic of $\mathrm{MCH}$ is the higher level of housing satisfaction experienced by house buyers $(\mu=3.68)$. These two statements illustrate the public-interest motivation among respondents, which has long been reported by other researchers (see for instance Campbell \& Marshall, 2000). Illegal renovations have long been a problem for Local Authorities, in terms of time and resources needed for enforcement and negative impact on the neighbourhood in terms of health and safety and aesthetics. $\mathrm{MCH}$ is seen as appealing to respondents because the customisation of the dwelling place to suit the needs of the occupants before occupation would greatly reduce the likelihood of the often illegal renovations. Having less illegal renovations would release the Local Authority's resources for other matters - staff training, technical upgrades, process improvements and other beneficial activities. On the other hand, higher housing satisfaction is seen to promote the well-being of occupants, a direct boost to public interest.

Table 3: Mean scores of MCH regulatory characteristics

\begin{tabular}{|c|c|}
\hline MCH regulatory characteristics & $\begin{array}{l}\text { Mean } \\
\text { Score }(\mu)\end{array}$ \\
\hline $\begin{array}{l}\text { Customised homes that can fulfil occupants' requirements from the beginning actually can help } \\
\text { development control in the long run as there will be less illegal renovations and extensions. }\end{array}$ & 3.92 \\
\hline $\begin{array}{l}\text { Buyers of a home that is built according to their preferences are expected to experience higher } \\
\text { housing satisfaction level than buyers of standard a home. }\end{array}$ & 3.68 \\
\hline $\begin{array}{l}\text { In balancing development control and economic realities, sometimes the approving authority has to } \\
\text { adopt a flexible attitude to ensure the viability of the project. }\end{array}$ & 3.58 \\
\hline $\begin{array}{l}\text { The justifications behind existing building regulations and requirements overrule new ideas in the } \\
\text { housing industry that are yet untested in the country. }\end{array}$ & 3.39 \\
\hline $\begin{array}{l}\text { A longer time is needed for the development approval of a proposed housing development } \\
\text { containing non-standard units in terms of finishes, fixtures and fittings and internal layout. }\end{array}$ & 3.24 \\
\hline
\end{tabular}

Respondents also showed high agreeableness that the approving authority has to be flexible to ensure the viability of the project $(\mu=3.58)$. Far from generalising, this indication can hint the regulators' willingness to apply a liberal interpretation of regulations when assessing a development approval application. When asked if legal justifications would overrule new untested housing 
innovation, respondents showed agreement $(\mu=3.39)$. This agreement confirms the above findings on the primacy of regulations and regulatory environment over developers' breakthroughs, no matter how potentially immensely beneficial they are in theory. Finally, respondents showed weak agreement that a longer time is needed to process an application for a MCH scheme $(\mu=3.24)$. This is because the technical department at the Local Authority is bound by the formal procedure practised in all Local Authorities in Malaysia, where processing time is set in the client's charter that must be observed.

Respondents were given five statements on the likely effect of $\mathrm{MCH}$ on development control whereby they indicated their response on a 5-point Likert scale ranging from $1=$ "Very negative" to $5=$ "Very positive". The aim of this line of query was to ascertain respondents' attitude towards the likely effect of $\mathrm{MCH}$ on development control. The results presented in Table 4 corroborated the earlier results pertaining to regulators' individual attitude and their perception of their department's attitude towards housing innovation. Overall, respondents had strong positive impressions on how $\mathrm{MCH}$ processes and features would interact with their development control dimension. Mean scores between 3.54 and 3.73 implied that respondents did not see $\mathrm{MCH}$ as a potential challenge to their statutory duties, but rather a complementary effort from the private sector in furthering the local authority's public interest objectives.

Table 4: Mean scores of impact of MCH on development control

\begin{tabular}{lc}
\hline Impact of MCH & $\begin{array}{c}\text { Mean Score } \\
(\mu)\end{array}$ \\
\hline Developer offers house buyers a house tailored to the house buyers preferences & 3.73 \\
House buyer has to spend more time selecting and deciding on preferred home specifications & 3.73 \\
The building plan submission can contain a higher range of building features and specifications & 3.73 \\
House buyers are able to choose building features according to preference & 3.68 \\
$\begin{array}{l}\text { Since houses are customised according to individual buyer's preferences, there may be a higher } \\
\text { degree of permutation of the completed units }\end{array}$ & 3.54 \\
\hline
\end{tabular}

In spite of the long-held perception of an opaque regulatory framework over housing provision in Malaysia, the above discussions show that there may be room for innovations, particularly those that offer benefits to house buyers without adding more to the current statutory provisions and procedures. On the surface, there seemed to be general attitudinal acceptance among building regulators towards $\mathrm{MCH}$. However, these results should be taken as a provisional tally. A more conclusive account on regulators' attitude towards $\mathrm{MCH}$ would be possible upon further probing, which is the aim of the qualitative part of the questionnaire. In other words, the institutional dynamic of building regulation would best be revealed by qualitative data that reflect the opinion and perception of regulators.

\subsection{Qualitative Results}

The open-ended question that solicited respondents' opinion on regulatory barriers to housing innovation yielded 23 responses, of which only 12 responses were selected to be discussed due to the quality of the argument. A thematic analysis revealed three main themes namely stakeholders' disconnect, compatibility and general mistrust. Within the SOP, the multiplicity of actors with different functions, objectives, experience levels and training background is a fertile ground for miscommunications, misconceptions and mistrust as perceived by the respondents and detected in their responses. The themes will be discussed in detail below.

\section{Stakeholders' Disconnect}

The variety in the quality and quantity of stakeholders caused concern among some respondents about the possible disconnect between different stakeholders in understanding and facilitating new ideas in housing. This disconnect could still be evident even between parties on the same side of the coin. For instance, Respondent 1 remarked about how new housing concepts could receive different treatments between two government agencies i.e. policy makers and local authorities. As mentioned by Respondent 1 : 
I see the Government making some initiatives in pushing this kind of (new) concepts though there may be some disconnection between the policy makers and local authorities in emphasizing importance. Respondent 1

Housing policy and regulations are administered in a top-down system in Malaysia (Agus, 2002). Policy makers who are mostly based in the administrative centre of Putrajaya may not be able to appreciate on-the-ground particulars and contemporary developments in the field. In the past, the blanket implementation of new regulations has tended to disregard the capability and capacity of local authorities in dispensing the new rules. Additionally, there was a lack of guidelines for reference in case of housing innovation. For junior architects, their inexperience may lead to overpromised products to their client that may not sit well with regulators bound by set standards and deadlines. This disengagement between young architects, clients and the authority was cited by Respondent 4:

No current guideline, policies have been developed (regarding housing innovations). Young designers lack knowledge, ethics and interpersonal skill (causing) lack of cooperation among designers, developers and policy makers. Respondent 4

The perception of Respondent 4 that stakeholders' disconnect can lead to a lack of cooperation among them hinted at a somewhat unfavourable regulatory environment in accepting new ideas in housing. Respondent 20's observation is along the same line with Respondent 4, again citing differences in actors' motivations and practices as the determinant of acceptance of housing innovations. These indications of scepticism hinted of the possessiveness of planners over public interest as argued by Campbell and Marshall (2000). However, Respondent 20 was more critical on how stakeholders define innovation, as sometimes innovation is promoted despite the seemingly insignificant departure from convention. As elaborated by Respondent 20:

Not because of outdated knowledge of the Local Authority, but because most developer/consultant are based on theory and are not knowledgeable in technical aspects and functionality details. The objective of innovation is more abstract than practical, more adaptation than invention. Design should not just be about concept but also involves passive and active designs. For instance, design using mechanical system does not promote natural design. So where is the innovation? Respondent 20

Despite the general positive reception indicated in the quantitative section of the questionnaire, the above responses revealed underlying concerns about how housing innovations would fit in the current regulatory framework. Sceptically, the new concepts or techniques in housing provision was described as being "more abstract than practical" by Respondent 20, with no real innovation. Anticipating a potential dis-uniformity, there was a mention about the need for a "guideline" for the reference of regulators (Respondent 4). However, this way of thinking is not innovation-friendly; as housing products rapidly change and developers constantly adapting to the changing socio-economic conditions, so must regulators and other government agencies. Regulators must be kept abreast with technological and conceptual improvements in the housing market so that proposed changes by developers that are buyer-oriented will not be hampered by regulators' outmoded way of thinking.

\section{Compatibility}

The second theme discerned from the qualitative responses was the compatibility of the proposed innovative ideas with existing development. The urban spatial environment was the result of past development control that was guided by statutory development plans at federal, state and local levels. These development plans were formulated after a painstaking process of survey, consultation and negotiation with various parties involving data trends and projections over a substantial period of time. Housing innovations are not covered by these statutory plans by virtue of their state-of-the-art nature; historic data simply could not forecast innovation due to the exponential rate of progress in 
technology. The 'fear of the unknown' caused Respondent 3 to query whether some new ideas in housing development will be compatible with existing developments:

In Malaysia, new ideas in housing development are encouraged in certain places, normally in urban areas. But somehow some concepts are not suitable with the surrounding areas as it will eventually could cause severe traffic jams and very high density housing area especially when the access infrastructure are remain undeveloped. Respondent 3

Malaysian development control authorities have been described as lacking in accuracy in housing demand estimations, leading to situations of oversupply in some localities and shortage in other market segments (Rameli et al., 2006). Innovations in housing do not seem to come into the equation, particularly MCH that has no influence on development density. The tendency to categorise housing innovations as homogeneous creations that may be incompatible with existing regulations was also projected by Respondents 11 and 26 in the following quotations:

(Housing innovation is) not objective oriented. It does not complement the existing laws. New technology must come with hand in hand with law amendment. Respondent 11

The authority always welcomes new ideas/suggestion from developer/public. Some regulation might be revoked/amended due to circumstances. Respondent 26

Not all housing innovations require adjustments in regulations, especially when concerning limited customisation. There are different degrees of customisation in MCH (Barlow et al., 2003), each with different legal implications. In an already heavily regulated housing market (see Hannah et al., 1989), there is no sense in adopting an $\mathrm{MCH}$ model that requires more regulation. Interestingly, there was a view that the additional development costs due to regulatory compliance can be offset against the benefits accrued in terms of sustainability and improvement in housing. Respondent 19 pondered this possibility:

Any innovative idea adds to the housing costs but developers are still encouraged to apply these ideas to ensure sustainability and improvement. Very welcome. Respondent 19

Compatibility issues observed among respondents concern the interaction between $\mathrm{MCH}$ and the spatial, legal and cost dimensions. The highlighted concerns only reflected misconceptions about the nature of housing innovations and the need to study the potential effects on case-by-case basis. The presumption of regulatory amendments for all housing innovations is a faulty one. Not all $\mathrm{MCH}$ models require adaptations of the current housing regulations. For instance, Customised Standardisation that offers non-spatial specification options such as interior finishing, types of doors and bath-core does not interfere with the building law.

\section{General mistrust}

Several responses revealed mistrust about actors' motivation due to the variation in actors' roles and objectives, with the majority of the respondents directing the scepticism towards developers. For these respondents, developers are generally the 'bad guys' looking out to make as much economic profits as possible from their ventures, at the expense of house buyers and regulations. The dogma of developers as profit-hungry cowboys is not a recent belief (Agus, 2004; Campbell \& Marshall, 2000). The negative nuances on developers' true motivations in adopting innovations are discernible from the following quotations:

Developers are more concerned about profits rather than suitable designs. Respondent 12

Certain standards and guidelines have the unflexibility to be implemented in terms of designing and providing space. This also refers to the developer as well. The developer only cares about profit and quality isn't looked at. Respondent 32 
It has always been possible to be flexible at the local authority. What happens is most developers are not clear about the development impact and more concerned about economic profit/benefits. Respondent 20

Clearly, there was a stigma attached to the business of housing development, particularly the perception of excessive profiteering among developers. Conversely, the authority was often seen as defenders of the people, operating to uphold public interest (Campbell \& Marshall, 2000). However, a respondent had a different opinion regarding the clear dichotomy of 'good government/bad developer', whereby the government was seen as facilitating developers' unethical activities. As reflected by Respondent 21:

Government doesn't care about the buyers' interest especially to control the price of the house but let the developer take advantage and gain as much profit from it. Respondent 21

However, Respondent 21 represented the lone voice of dissent regarding the government's motive in housing matters among respondents, and is likely the true depiction of the overall trust rather than distrust in the government in the field. Nonetheless, the general distrust in developers extended to their agents, particularly architects and engineers. A rather strong opinion about the professionalism, or lack thereof, of development consultants was dispensed by Respondent 4:

Nowadays, architects \& engineers are very irresponsible to what they produced. Lack of ethics and irresponsible manners-therefore, an innovation of housing development cannot be achieved. Respondent 4

As stated in Farr (2013), the biggest hurdle in convincing the actors in housing provision to adopt $\mathrm{MCH}$ is tackling the mind-set of the actors who were entrenched in the tried-and-tested traditional housing development system. This sentiment can be discerned by the quotations that implied respondents' mistrust about actors' motivations in introducing housing innovations. Respondents described developers as profit-driven whereas consultants lacking ethics and responsibility. Farr (2013) called for a paradigm-shift among the actors, in this case the regulators, in exploring the potentials of a concept in housing that could enhance house buyers' satisfaction and reduce waste. Ultimately, $\mathrm{MCH}$ can preserve public interest by fulfilling the needs of occupants and protecting the scarce resources that otherwise would be consumed by house modifications.

\subsection{Discussion}

Three main points stood out from the above discussions.

Firstly, there was a general consensus among respondents on the social benefits of $\mathrm{MCH}$ as an innovative housing concept with potentials on building control in the long run based on the argument that houses that are customised already accommodate some or most of occupants' requirements. Issues of illegal housing modification and low housing satisfaction levels were perceived as being addressed by $\mathrm{MCH}$. As such, $\mathrm{MCH}$ received a discernible support among respondents who were basically public servants trained to uphold matters of the public interest.

Secondly, despite the general receptivity for $\mathrm{MCH}$, some prejudices pertaining to the formal rules still persisted among respondents. There was agreement at both departmental and general development control levels that rigid building standards and requirements could pose the most serious barriers to housing innovations, including $\mathrm{MCH}$. Analysis of qualitative responses offered an explanation to this result. Apparently, 'housing innovations' were a catch-all for anything outside the conventional housing model, without regard to the myriad of new construction technologies, business models and development concepts that could be used to transform housing production. Some innovations, the Customised Standardisation MCH model included, do not concern layout or structural elements and thus should not be impeded by building standards and requirements. Local building 
regulators, without a valid motivation to keep abreast with developments within the housing industry will fail to grasp these subtleties.

Thirdly and finally, the qualitative data revealed a tone of hostility towards housing developers. Seen as greedy and money-grubbing capitalists, motivations of developers were suspect whilst their agents and associates were seen as extensions of their unscrupulousness. Whilst such preconceptions on developers are not unique to Malaysia, this negativity had prevailed for a long time despite the many contributions by developers, such as the production of low-cost housing via the mandatory low-cost housing quota, public amenities and facilities resultant from planning obligations, and corporate social responsibility projects. Developers may face an uphill struggle to convince local building regulators about the genuineness of an innovative housing concept when regulators already have preconceived notions about developers' motivations.

\subsection{CONCLUSION AND RECOMMENDATIONS}

$\mathrm{MCH}$ is a form of housing innovation with great promise in the enhancement of social, environmental and economic aspects of housing. It is perhaps easier to convince house buyers and developers about the many benefits of $\mathrm{MCH}$ implementation compared to regulators who are perhaps constrained by their legal duties and procedures, weighed down by the sheer volume of development applications and wary about the motivations behind the so-called housing innovation. Yet, in many countries $\mathrm{MCH}$ has been accepted as a norm in the housing industry. In the era of "experience economy" (Pine \& Gilmore, 2011), consumer centricity can no longer be an option for businesses to remain competitive. At the same time, houses built to customer specification may reduce the likelihood of future or illegal building modifications which could significantly reduce monitoring and enforcement efforts of building regulators.

This paper has explored the views of local building regulators about the suitability of MCH within the prevalent regulatory environment. In weighing the expected benefits against the expected costs of MCH implementation, the respondents in this study express their general acceptance of $\mathrm{MCH}$ in the close ended questions. However, when the line of query was opened to probe in more detail any reservations about $\mathrm{MCH}$ implementation, the qualitative responses yielded issues regarding stakeholders' readiness, MCH's compatibility with the existing system and development actors' motivations. However, most of these worries developed out of local building regulators' apprehension about and non-understanding of the nature of housing innovations. Most of these concerns over how $\mathrm{MCH}$ would fit in the current regulatory environment can be managed by exposing and educating the authority about successful MCH implementation in other countries and also the different types of customisation. The right amount and combination of exposure and education can help to alleviate negative perceptions of housing innovations. For instance, local building regulators can benefit from undertaking industrial attachments that not only will update their knowledge about the housing industry but also pave the way for more amicable public-private partnerships in the future.

Regardless of the valuable insights generated, this study is only part of a bigger study that looks into the systematic implementation of mass customisation in the Malaysian housing market. Besides regulators' readiness in embracing $\mathrm{MCH}$, studies on the perceptions of house buyers and developers and the technical readiness had also been conducted, results of which to be read together to enable a more holistic interpretation of how $\mathrm{MCH}$ would integrate into the current structure of housing provision. 


\subsection{REFERENCES}

Adams, D. (2008). Mapping out the regulatory environment and its interaction with land and property markets. Energy Policy, 36, 4570-4574.

Adams, D., Dunse, N., \& White, M. (2005). Conceptualising state-market relations in land and property: The mainstream contribution of neo-classical and welfare economics. In D. Adams, C. Watkins \& M. White (Eds.), Planning, public policy and property markets (pp. 17-35). Oxford: Blackwell Publishing.

Adams, D., Leishman, C., \& Watkins, D. (2012). Housebuilder networks and residential land markets. Urban Studies, 49(4), 705-720.

Adams, D., Watkins, C., \& White, M. (2005). Planning, public policy and property markets: Current relations and future challenges. In D. Adams, C. Watkins \& M. White (Eds.), Planning, public policy \& property markets (pp. 239-251). Oxford: Blackwell Publishing.

Agus, M. R. (2002). The role of state and market in the Malaysian housing sector. Journal of Housing and the Built Environment, 17, 49-67.

Agus, M. R. (2004). Syarahan Perdana Mencari tempat berteduh, mengejar rumah impian: Pengabaian kolonial, keserakahan spekulator (Plenary Speech "Looking for shelter, chasing after the dream home: Colonial neglect, speculator's greed". Kuala Lumpur: Universiti Malaya.

Andújar-Montoya, M. D., Gilart-Iglesias, V., Montoyo, A., \& Marcos-Jorquera, D. (2015). A construction management framework for mass customisation in traditional construction. Automation in Construction, 7(5), 5182-5210.

Awuah, K. G. B., \& Hammond, F. N. (2014). Determinants of low land use planning regulation compliance rate in Ghana. Habitat International, 41(17-23).

Ball, M. (1983). Housing policy and economic power: The political economy of owner occupation. London: Methuen \& Co Pte Ltd.

Ball, M. (1986). Housing analysis: time for a theoretical refocus? Housing Studies, 1(3), 147-166.

Ball, M. (1998). Institutions in British property research: A review. Urban Studies, 35(9), 1501-1517.

Ball, M. (2003). Markets and the structure of the housebuilding industry: An international perspective. Urban Studies, 40(5-6), 897-916.

Ball, M. (2010). Planning delay and the responsiveness of English housing supply. Urban Studies, 114.

Ball, M., \& Harloe, M. (1992). Rhetorical barriers to understanding housing provision: What the 'provision thesis' is and is not. Housing Studies, 7(1), 3-15.

Barlow, J. (1999). From craft production to mass customisation: Innovation requirements for the UK housebuilding industry. Housing Studies, 14(1), 23-42. doi: http://www.tandfonline.com/doi/abs/10.1080/02673039982984\#.VIqetPmSySo

Barlow, J., Childerhouse, P., Gann, D., Hong-Minh, S., Naim, M., \& Ozaki, R. (2003). Choice and delivery in housebuilding: lessons from Japan for UK housebuilders. Building Research \& Information, 31(2), 134-145. doi: 10.1080/09613210302003 
Barlow, J., \& Ozaki, R. (2003). Achieving'customer focus' in private housebuilding: Current practice and lessons from other industries. Housing Studies, 18(1), 87-101.

Bertaud, A., \& Malpezzi, S. (2001). Measuring the costs and benefits of urban land use regulations: A simple model with an application to Malaysia. Journal of Housing Economics, 10, 393-418.

Bramley, G., \& Leishman, C. (2005). Planning and housing supply in two-speed Britain: Modelling local market outcomes. Urban Studies, 42(12), 2213-2244.

Burke, T., \& Hulse, K. (2010). The institutional structure of housing and the sub-prime crisis: An Australian case study. Housing Studies, 25(6), 821-836.

Campbell, H., \& Marshall, R. (2000). Moral obligations, planning, and the public interest: A commentary on current British practice. Environment and Planning B: Planning and Design, 27, 297-312.

Chua, Y. P. (2013). Mastering Research Statistics. Selangor, Malaysia: McGraw Hill Education.

Duarte, J. P. (2005). Towards the mass customization of housing: The grammar of Siza's houses at Malagueira. Environment and Planning B: Planning and Design, 32, 347-380.

Farr, E. R. P. (2013). Spatial mass customisation: mass-customisable urban spaces and spatial entities. In P. A. E. Piroozfar \& F. T. Piller (Eds.), Mass Customisation and Personalisation in Architecture and Construction (pp. 53-64): Routledge.

Fogliatto, F. S., Da Silveira, G. J. C., \& Borenstein, D. (2012). The mass customization decade: An updated review of the literature. International Journal of Production Economics, 138(1), 1425 .

Gann, D. M., Wang, Y., \& Hawkins, R. (1998). Do regulations encourage innovation? - the case of energy efficiency ni housing. Building Research \& Information, 26(5), 280-296.

Gao, Y. (2014). Mass Customize Housing With Computation. Faculty of Architecture, the University of Hong Kong: Seed Funding Programme for Basic Research.

Hamzah, H. (2012). State intervention in housing the urban poor in the developing State of Terengganu in Malaysia: An institutional analysis of low-cost housing regulations and their impacts on low-cost housing provision. PhD Thesis, University of Auckland, Auckland, New Zealand.

Hamzah, H. (2013). Econometric modelling or institutionalism? A review of the main approaches in analyses of housing regulation. Jounal of Design and Built Environment, 12(1), 1-12.

Hamzah, H., \& Wan Abd. Aziz, W. N. A. (2013). An institutional analysis of housing delivery improvements: A Malaysian case study Contemporary Legal and Economic Issues, 4, 94-120.

Hannah, L., Bertaud, A., Malpezzi, S., \& Mayo, S. (1989). Malaysia: The housing sector; getting the incentives right: World Bank Sector Report 7292-MA.

Hodgson, G. M. (1998). The approach of institutional economics. Journal of Economic Literature, 36(1), 166-192.

Hodgson, G. M. (2000). What is the essence of institutional economics? Journal of Economic Issues, 34(2), 317. 
Malpezzi, S., \& Mayo, S. K. (1997). Getting housing incentives right: A case study of the effects of regulation, taxes and subsidies on housing supply in Malaysia. Land Economics, 73(3), 372391.

Murphy, L. (2011). The global financial crisis and the Australian and New Zealand housing markets. Journal of Housing and the Built Environment, 26(3).

Naim, M., \& Barlow, J. (2003). An innovative supply chain strategy for customized housing. Construction Management and Economics, 21(6), 593-602.

Noguchi, M. (2003). The effect of the quality-oriented production approach on the delivery of prefabricated homes in Japan. Journal of Housing and the Built Environment, 18, 353-364.

Noguchi, M., \& Hadjri, K. (2009). Mass custom design for sustainable housing development Handbook of research in mass customization and personalization.

Pine, B. J., \& Gilmore, J. H. (2011). The experience economy. US: Harvard Business Press.

Pine II, B. J. (1999). Mass customization : the new frontier in business competition: Harvard Business Press.

Puligadda, S., Grewal, R., Rangaswamy, A., \& Kardes, F. R. (2010). The role of idiosyncratic attribute evaluation in mass customization. Journal of Consumer Psychology, 20, 369-380.

Rameli, A., Johar, F., \& Ho, C. S. (2006). Responsiveness of the Malaysian planning system in managing housing supply. Paper presented at the International Conference on Sustainable Housing 2006, University Sains Malaysia, Penang, Malaysia. http://eprints.utm.my/6321/1/Alias_DrFoziah_DrHCSiong2006_ResponsivenssOfTheMalaysi anPlanning.pdf

Samuels, W. J. (1995). The present state of institutional economics. Cambridge Journal of Economics, $19,569-590$.

Satsangi, M. (2005). Landowners and the structure of affordable housing provision in rural Scotland. Journal of Rural Studies, 21, 349-358.

Satsangi, M. (2011). Feminist epistemologies and the social relations of housing provision. Housing, Theory and Society, 28(4), 398-409.

Satsangi, M., \& Dunmore, K. (2003). The planning system and the provision of affordable housing in rural Britain: A comparison of the Scottish and English experience. Housing Studies, 18(2), 201-217.

Schoenwitz, M., Naim, M., \& Potter, A. (2012). The nature of choice in mass customized house building. Construction Management and Economics, 30, 203-219.

Shin, Y., An, S. H., Cho, H. H., Kim, G. H., \& Kang, K. I. (2008). Application of information technology for mass customization in the housing construction industry in Korea. Automation in Construction, 17, 831-838.

Singapore HDB. (2015). Types of Flats: Design Features, from http://www.hdb.gov.sg/fi10/fi10321p.nsf/w/BuyingNewFlatDesignFeatures?OpenDocument

Sufian, A., \& Ab. Rahman, R. (2008). Quality housing: Regulatory and administrative framework in Malaysia. Int. Journal of Economics and Management, 2(1), 141-156. 
e-issn: $2229-8568$

Sundbo, J., \& Sørensen, F. (2013). Handbook on the Experience Economy. Cheltenham, UK: Edward Elgar Publishing.

Tseng, M. M., \& Du, X. (1998). Design by customers for mass customization products. CIRP AnnalsManufacturing Technology, 47(1), 103-106. doi: $\underline{\text { http://ac.els- }}$ cdn.com/S0007850607627954/1-s2.0-S0007850607627954-main.pdf? tid=b24ae922-81d5$\underline{11 \mathrm{e} 4-9 \mathrm{ed} 2-00000 \mathrm{aacb} 360 \& \mathrm{acdnat}=1418371734 \quad 1 \mathrm{e} 554088 \mathrm{~cd} 3 \mathrm{cac} 545568 \mathrm{f} 945 \mathrm{fb} 1 \mathrm{e} 2783}$

Yates, S. R., \& Worzala, E. M. (2013). Real estate and complexity economics. Journal of Property Investment \& Finance, 31(1).

Yau, Y. (2009). On the proposed private certification of building works in Hong Kong. International Journal of Law in the Built Environment, 1(3), 221-233.

Zipkin, P. (2001). The Limits of Mass Customization. MIT Sloan Management Review, 42/3(Spring), 81 . 